\title{
Microbial Ingrowth Around Single- and Multi-Component Adhesives Studied in vitro
}

\author{
S. Preussker ${ }^{a} \quad$ W. Klimm ${ }^{a} \quad$ M. Pöschmanna R. Koch ${ }^{b}$ \\ aDepartment of Conservative Dentistry and ${ }^{\mathrm{b}}$ Institute of Informatics and Biometrics, \\ University Clinic Carl Gustav Carus, Dresden, Germany
}

\section{Key Words}

Composites - Dental materials - Dentin-bonding agents · Microbial leakage - Multi-component dental adhesives Single-component dental adhesives

\begin{abstract}
The aim of this study was to compare the in vitro microbial leakage in 4 micro-hybrid composites in combination with 4 single-component dental adhesives (Scotchbond 1/Z100 MP = group 1; Syntac Single-Component/ Tetric Flow = group 3; OptiBond Solo/XRV Herculite = group 5; Solobond M/Arabesk Top = group 7) and 4 multi-component dental adhesives (Scotchbond Multi-Purpose/Z100 MP = group 2; Syntac/Tetric Flow = group 4; OptiBond FL/XRV Herculite = group 6; Solobond Plus/ Arabesk Top = group 8). Ninety-four mixed standardized Class $\mathrm{V}$ cavities of human caries-free extracted premolars were filled with eight different composite adhesive systems using a one-layer (groups 1-4) or a two-layer technique (groups 5-8). After thermocycling and incubation in a broth culture of Streptococcus mutans and Lactobacillus acidophilus, followed by decalcification and staining, the extent and the type of microbial leakage were measured histologically. The extent of microbial
\end{abstract}

leakage in the composite restorations was very low in all groups and there were no significant differences between adhesives. Z100 MP in combination with singleand multi-component adhesives showed a significantly higher microbial leakage than Tetric Flow systems ( $U$ test: $p=0.037$ ). XRV Herculite adhesive systems showed significantly less extensive microbial leakage than Arabesk Top adhesive systems ( $U$ test: $p<0.001$ ). The single-component dental adhesives achieved a marginal adaptation of composites comparable to that of multicomponent adhesives in vitro.

Copyright $@ 2003$ S. Karger AG, Basel

Microbial leakage at the marginal gap between restoration and tooth surface is a potential caries risk factor as well as an indicator for the curative value of restorative materials [Klimm et al., 1996]. The quality and aesthetics of composite restorations are mainly determined by the marginal adaptation of composite materials. In this context adhesive systems play a key role [Lutz et al., 1993]. Composite-enamel bonding has been proven reliable by the application of the adhesive technique. The dentincomposite bond is more problematic. First attempts were made in the 1960s when dentin adhesives of the first gen-

\section{KARGER}

Fax +41613061234

E-Mail karger@karger.ch

www.karger.com
(C) 2003 S. Karger AG, Basel

0008-6568/03/0375-0345\$19.50/0

Accessible online at:

www. karger.com/cre
Dr. Susann Preussker

University Clinic Carl Gustav Carus, Department of Conservative Dentistry

Fetscherstrasse 74, DE-01307 Dresden (Germany)

Tel. +49 3514582713 , Fax +49 3514585381

E-Mail susann.preussker@mailbox.tu-dresden.de 
eration were developed [Schäfer, 1999]. In the 1970s, Fusayama [1990, 1997] introduced dentin etching using a phosphoric-acid gel to form micro-mechanical retention in dentin by dissolving smear plugs within the tubules. Due to strong international opposition to dentin etching, this technique did not become generally accepted until the 1990s [Fusayama, 1997]. The fourth generation of adhesives requires total etching of dentin and enamel [Schäfer, 1999]. The quality of the marginal adaptation has been clearly improved through the consistent use of micromechanical retention within the dentin [Haller, 1994]. Dentin bonding was still complicated by the three-step procedure, comprising conditioning, priming and bonding. Along with the improvement of the adhesion to the dentin, the goal of these developments was to reduce the number of necessary components in order to simplify its use, avoid errors and reduce the time needed for treatment. Dentin adhesives of the third and fourth generation (multi-component dental adhesives) were developed into a fifth generation (single-component dental adhesives) [Schäfer, 1999]. With multi-component dental adhesives, the primer and adhesive are applied separately. With single-component dental adhesives, the primer and adhesive come already combined and are then applied 1-2 times to the cavity surface. The newest development in this area are the self-conditioning, non-rinsing dentin adhesives, with which the special conditioner does not need to be rinsed away [Dammaschke and Schäfer, 2000].

The relative merits of the single-component versus the multi-component dental adhesives in regard to bonding with the tooth can be determined through shear bond strength tests, dye penetration tests and morphological examinations of restorations [Blunck, 1996]. Opinions vary as to the success of single-component adhesives. Some experts are cautious to recommend the single-component adhesives because of their lesser bond strength as well as a lack of significant gains in the time of application [Hickel, 1997]. Haller and Fritzenschaft [1999] found that on both dry and moist dentin multi-component dental adhesives formed a significantly stronger bond. Some multi-component adhesives exhibited better marginal adaptation than some of the single-component adhesives. Abdalla and Davidson [1998] found that the single-component adhesives formed a weaker bond to the dentin. Other authors determined, however, that there are singlecomponent dental adhesives whose in vitro bond strengths for enamel and dentin as well as hybrid zone formation were equivalent to conventional multi-component dental adhesives [Vargas et al., 1997; Swift et al., 1998].
The aim of this study was to compare the microbial leakage of composite restorations with single-component and multi-component dental adhesives using an in vitro microbiological test system [Klimm et al., 1996].

\section{Materials and Methods}

Caries-free human permanent premolars, extracted for orthodontic reasons, were used. The teeth were freed from periodontal fibers, cleaned with Clean Polish (Hawe Neos, Gentilino, Switzerland), examined for cracks, caries and restorations using a magnifying glass and stored in artificial saliva (standard formula: $12.5 \mathrm{~g}$ of $4 \%$ hydroxyethyl cellulose gel; $4.28 \mathrm{~g}$ of $70 \%$ sorbitol solution; $0.12 \mathrm{~g} \mathrm{KCl}$; $0.08 \mathrm{~g} \mathrm{NaCl} ; 0.06 \mathrm{~g} \mathrm{Na}_{2} \mathrm{HPO}_{4} \cdot 12 \mathrm{H}_{2} \mathrm{O} ; 0.02 \mathrm{~g} \mathrm{CaCl}_{2} \cdot 2 \mathrm{H}_{2} \mathrm{O} ; 0.01 \mathrm{~g}$ $\mathrm{MgCl}_{2} \cdot 6 \mathrm{H}_{2} \mathrm{O} ; 82.9 \mathrm{~g}$ conserved water). Under aseptic conditions (surgical hand disinfection, sterile gloves, face mask, 2-min surface disinfection with $3 \%$ hydrogen peroxide and $0.5 \%$ alcoholic chlorhexidine digluconate, sterile instruments and rotary instruments, sterile filtered compressed air, cooling with sterile distilled water) the teeth were apically sealed in order to prevent retrograde bacterial penetration. Following the apical reduction of the roots and apical cavity preparation, the teeth were apically sealed employing the following three steps: (1) zinc oxide-eugenol (University Clinic Dresden), (2) Harvard cement, normally hardening (Harvard Dental $\mathrm{GmbH}$, Berlin) and (3) OptiBond ${ }^{\mathrm{TM}} \mathrm{FL}$ (Kerr, Orange, Calif., USA).

Class $\mathrm{V}$ restorations were placed in 48 premolars. Two cavities were prepared per tooth, one in the vestibular, the other in the oral surface. In each of the 8 test groups, 6 teeth with 12 cavities were used. Under aseptic conditions, standardized Class V cavities with their cervical margins below the cementoenamel junction were prepared with a high-speed, pear-shaped medium-grain diamond instrument $(120,000 \mathrm{rpm})$ and finished at 40,000 rpm using a high-speed, pear-shaped fine-grain diamond instrument. Sterile water-cooling was maintained throughout. The cavities measured $3 \mathrm{~mm}$ mesio-distally, $2.5 \mathrm{~mm}$ inciso-apically and were $2 \mathrm{~mm}$ deep. A $1-\mathrm{mm}$ bevel was placed on the coronal margin with a high-speed, flame-shaped finegrain diamond $(40,000 \mathrm{rpm})$ with water-cooling. The eight composite adhesive systems tested are listed in table 1. A one-layer technique was used for groups 1-4, and a two-layer technique (first layer apically, second layer coronally) was used for groups 5-8. All fillings were applied according to the manufacturer's instructions (table $2 a, b$ ). After placing, the restorations were contoured and polished with a fine-grain, flame-shaped high-speed diamond $(40,000 \mathrm{rpm})$ with water-cooling, low-speed silicone polishers $(8,000 \mathrm{rpm})$ with water spray and polishing discs $(8,000 \mathrm{rpm})$. For purposes of simulating temperature change stresses, the filled teeth were thermocycled in an artificial saliva solution $\left(5^{\circ} \mathrm{C} / 55^{\circ} \mathrm{C}\right.$, groups $1-4$ : 5,200 cycles; groups 5-8: 5,000 cycles; duration of cycles: $70 \mathrm{~s}$ ). Afterwards, the apical sealing with OptiBond ${ }^{\mathrm{TM}} \mathrm{FL}$ (Kerr) was repeated. The filled teeth were then incubated for 8 weeks at $37^{\circ} \mathrm{C}$ with a broth culture; $0.1 \mathrm{ml}$ of thioglycollate broth cultures of wild strain Streptcoccus mutans and Lactobacillus acidophilus $\left(10^{8} \mathrm{CFU} / \mathrm{ml}\right)$ were transferred to tubes containing filled teeth and filled to $5 \mathrm{ml}$ with thioglycollate medium (Oxoid, Unipath Ltd., Hampshire, UK). The incubation medium was renewed every $48 \mathrm{~h}$. The cultures were checked biochemically and for cell and colony morphology. After fixation in a formaldehyde solution ( $5 \%$, phosphate-buffered at $\mathrm{pH} 7$ ) for 7 days, 
Table 1. Composite adhesive systems used

\begin{tabular}{|c|c|c|c|}
\hline Dental adhesive & Composite & Manufacturer & $\begin{array}{l}\text { Group } \\
\text { number }\end{array}$ \\
\hline \multicolumn{4}{|c|}{ Single-component dental adhesives } \\
\hline Scotchbond 1 & $\mathrm{Z100} \mathrm{MP}$ & 3M, St. Paul, Minn., USA & 1 \\
\hline Syntac Single-Component & Tetric Flow & Vivadent, Schaan, Liechtenstein & 3 \\
\hline OptiBond Solo & XRV Herculite & Kerr, Orange, Calif., USA & 5 \\
\hline Solobond M & Arabesk Top & Voco, Cuxhaven, Germany & 7 \\
\hline \multicolumn{4}{|c|}{ Multi-component dental adhesives } \\
\hline Scotchbond Multi-Purpose & Z100 MP & $3 \mathrm{M}$ & 2 \\
\hline Syntac & Tetric Flow & Vivadent & 4 \\
\hline OptiBond FL & XRV Herculite & Kerr & 6 \\
\hline Solobond Plus & Arabesk Top & Voco & 8 \\
\hline
\end{tabular}

Table 2. Application procedure of composite adhesive systems according to manufacturer's instructions

\begin{tabular}{|c|c|c|c|c|}
\hline $\mathbf{a}$ & Scotchbond 1/Z100 MP & $\begin{array}{l}\text { Scotchbond Multi- } \\
\text { Purpose/Z100 MP }\end{array}$ & $\begin{array}{l}\text { Syntac Single- } \\
\text { Component/Tetric Flow }\end{array}$ & Syntac/Tetric Flow \\
\hline $\begin{array}{l}\text { Etching (total etching tech- } \\
\text { nique of enamel and dentin } \\
\text { with a phosphoric acid gel) }\end{array}$ & \multicolumn{2}{|c|}{$\begin{array}{l}\text { Scotchbond etchant: application to enamel and dentin, } \\
\text { waiting } 15 \mathrm{~s} \text {, rinsing } 10 \mathrm{~s} \text {, removing excess water with an } \\
\text { air syringe (but leaving moist), wet bonding technique }\end{array}$} & $\begin{array}{l}\text { Email Preparator } G S \text { : } \\
\text { application to enamel and } \\
\text { dentin, waiting } 15 \mathrm{~s} \text {, rinsing } \\
10 \mathrm{~s} \text {, removing excess water } \\
\text { with an air syringe (but } \\
\text { leaving moist), wet bonding } \\
\text { technique }\end{array}$ & $\begin{array}{l}\text { Email Preparator } G S \text { : } \\
\text { etching of enamel } 30 \mathrm{~s} \text {, } \\
\text { etching of dentin } 15 \mathrm{~s} \text {, rinsing } \\
\text { for } 10 \mathrm{~s} \text {, drying thoroughly }\end{array}$ \\
\hline Priming and bonding & $\begin{array}{l}\text { Scotchbond } 1 \text { adhesive: } \\
\text { application of } 2 \text { consecutive } \\
\text { coats, drying gently with air } \\
3 \mathrm{~s} \text {, light curing } 10 \mathrm{~s}\end{array}$ & $\begin{array}{l}\text { Scotchbond multi-purpose } \\
\text { primer: application of } 1 \text { layer, } \\
\text { drying gently with air } 5 \mathrm{~s} \\
\text { Scotchbond multi-purpose } \\
\text { adhesive: application, light } \\
\text { curing } 10 \mathrm{~s}\end{array}$ & $\begin{array}{l}\text { Syntac Single-Component: } \\
\text { application of first coat, wait- } \\
\text { ing } 20 \mathrm{~s} \text {, drying with air, light } \\
\text { curing } 20 \mathrm{~s} \text {, application of } \\
\text { second coat, drying with air, } \\
\text { light curing } 20 \mathrm{~s}\end{array}$ & $\begin{array}{l}\text { Syntac primer: application of } \\
1 \text { layer, waiting } 15 \mathrm{~s} \text {, drying } \\
\text { thoroughly with air } \\
\text { Syntac adhesive: application, } \\
\text { waiting } 10 \mathrm{~s} \text {, drying with air } \\
\text { Heliobond: application, wait- } \\
\text { ing } 10 \mathrm{~s} \text {, blowing off excess } \\
\text { with air, light curing } 10 \mathrm{~s}\end{array}$ \\
\hline
\end{tabular}

Composite application Z100 MP: application in one-layer technique, light curing $40 \mathrm{~s} \quad$ Tetric Flow: application in one-layer technique, light curing $40 \mathrm{~s}$

\begin{tabular}{|c|c|c|c|c|}
\hline b & $\begin{array}{l}\text { OptiBond Solo/XRV } \\
\text { Herculite }\end{array}$ & OptiBond FL/XRV Herculite & Solobond M/Arabesk Top & Solobond Plus/Arabesk Top \\
\hline $\begin{array}{l}\text { Etching (total etching tech- } \\
\text { nique of enamel and dentin } \\
\text { with a phosphoric acid gel) }\end{array}$ & $\begin{array}{l}\text { Kerr Gel Etchant: application } \\
\text { to enamel and dentin, waiting } \\
15 \mathrm{~s} \text {, rinsing } 15 \mathrm{~s} \text {, lightly } \\
\text { drying without desiccation } \\
\text { of dentin, wet bonding } \\
\text { technique }\end{array}$ & $\begin{array}{l}\text { Kerr Gel Etchant: etching of } \\
\text { enamel } 30 \mathrm{~s} \text {, etching of dentin } \\
15 \mathrm{~s} \text {, rinsing } 15 \mathrm{~s} \text {, lightly } \\
\text { drying without desiccation } \\
\text { of dentin, wet bonding } \\
\text { technique }\end{array}$ & \multicolumn{2}{|c|}{$\begin{array}{l}\text { Vococid: etching of enamel } 30 \mathrm{~s} \text {, etching of dentin } 15 \mathrm{~s} \text {, rinsing } \\
20 \mathrm{~s} \text {, lightly drying without desiccation of dentin, wet bonding } \\
\text { technique }\end{array}$} \\
\hline Priming and bonding & $\begin{array}{l}\text { OptiBond Solo: application of } \\
1 \text { layer with light brushing } \\
\text { motion } 15 \mathrm{~s} \text {, drying gently } \\
\text { with air } 5 \mathrm{~s} \text {, light curing } 20 \mathrm{~s}\end{array}$ & $\begin{array}{l}\text { OptiBond FL Prime: } \\
\text { application of } 1 \text { layer with } \\
\text { light brushing motion } 30 \mathrm{~s} \text {, } \\
\text { drying gently with air } 5 \mathrm{~s} \\
\text { OptiBond FL Adhesive: } \\
\text { application, blowing off ex- } \\
\text { cess with air, light curing } 30 \mathrm{~s}\end{array}$ & $\begin{array}{l}\text { Solobond } M \text { : application of } \\
\text { first coat, waiting } 30 \mathrm{~s} \text {, dis- } \\
\text { persion with a faint air jet, } \\
\text { light curing } 20 \mathrm{~s}\end{array}$ & $\begin{array}{l}\text { Solobond Plus Primer: } \\
\text { application of } 1 \text { layer only on } \\
\text { dentin with light brushing mo- } \\
\text { tion } 30 \mathrm{~s} \text {, drying thoroughly } \\
\text { with air } \\
\text { Solobond Plus Adhesive: } \\
\text { application on dentin and } \\
\text { enamel with light brushing } \\
\text { motion } 15 \mathrm{~s} \text {, drying gently } \\
\text { with air, light curing } 20 \mathrm{~s}\end{array}$ \\
\hline Composite application & \multicolumn{2}{|c|}{$\begin{array}{l}X R V \text { Herculite: application in two-layer technique } \\
\text { (first layer apical, second layer coronal), light curing each } \\
\text { increment for } 40 \mathrm{~s}\end{array}$} & \multicolumn{2}{|c|}{$\begin{array}{l}\text { Arabesk Top: application in two-layer technique } \\
\text { (first layer apical, second layer coronal), light curing each } \\
\text { increment for } 40 \mathrm{~s}\end{array}$} \\
\hline
\end{tabular}




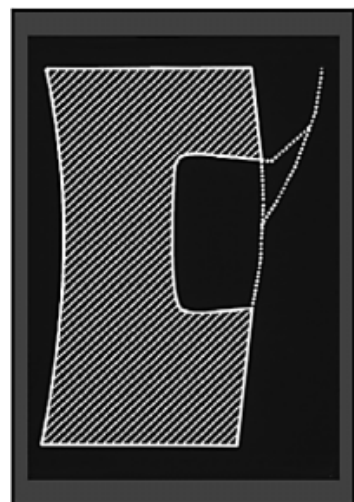

Score 0

no microorganisms in cavity

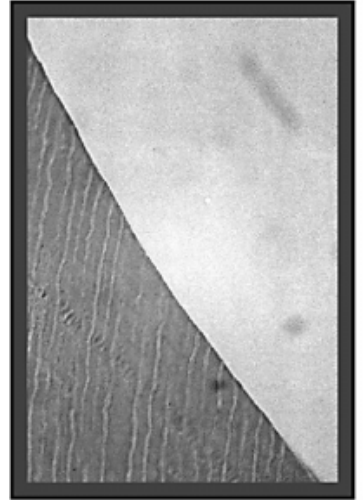

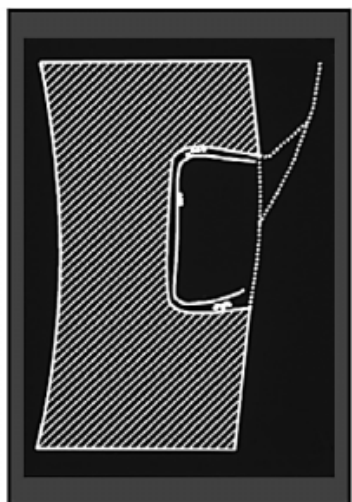

\section{Score 1}

single microorganisms at the cavity wall and / or within the detached layer

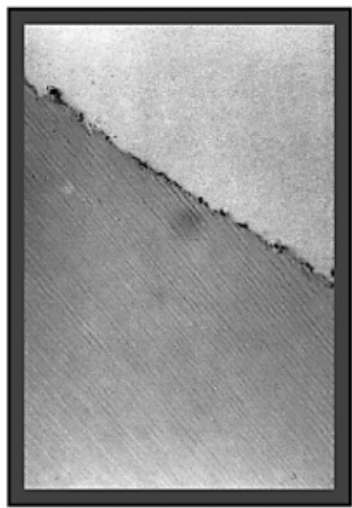

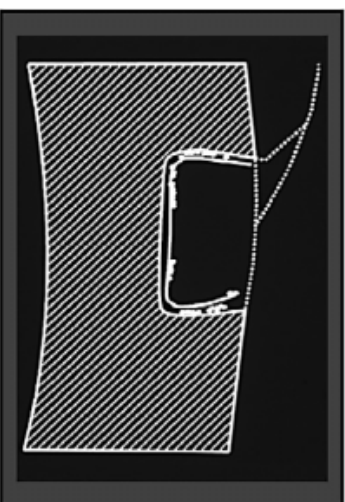

\section{Score 2}

Score 3 cavity wall or to the detached layer

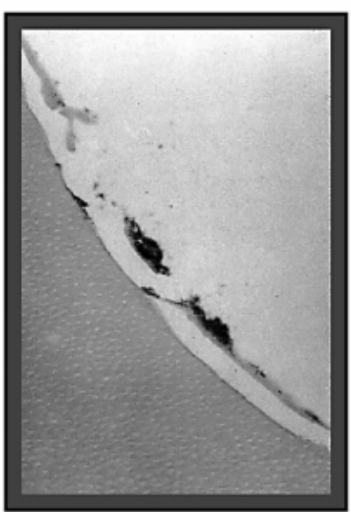

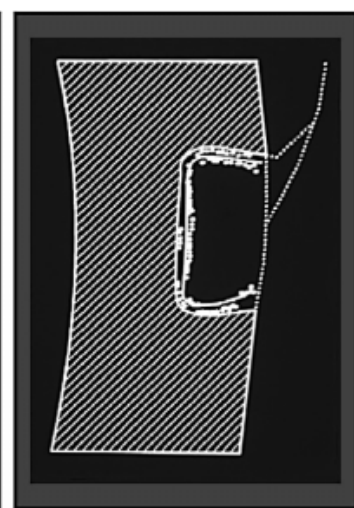
neous colonization of the de- dentinal tubules tached layer

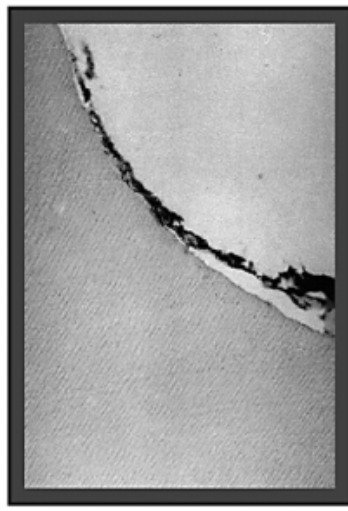

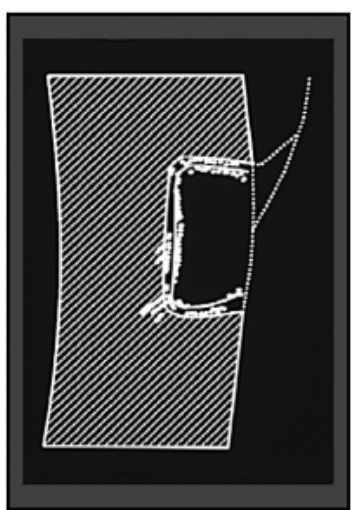

Score 4

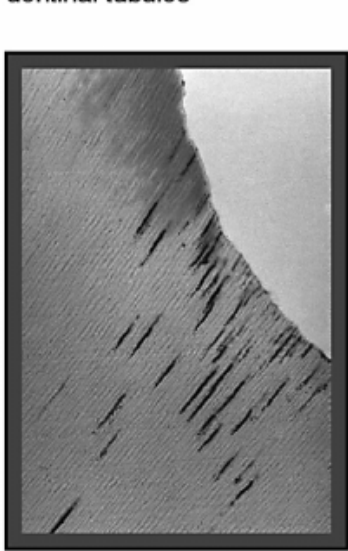

Fig. 1. Extent of microbial leakage according to Klimm et al. [1996].

washing in water, decalcification in EDTA $(20 \%$, pH 7.4, for 12 weeks at $37^{\circ} \mathrm{C}$, changed twice weekly), removal of the fillings and embedding in paraffin, the teeth were sectioned. Six sections 5- to $7-\mu \mathrm{m}$ thick were cut from 6 evenly spaced locations of each cavity and subsequently deparaffinized and stained according to Brown and Brenn [1931]. The examination involved 72 sections per group (12 cavities), except in groups 5 and 6 , where sections of 1 cavity per group were lost during cutting.

The extent and pattern of microbial colonization of the marginal gaps were ascertained histologically [Klimm et al., 1996]. The extent of microbial colonization (fig. 1) is a ranked variable ranging from score 0 (no microorganisms in cavity) to score 4 (microbial layer at cavity wall and microbial penetration of dentinal tubules) [Klimm et al., 1996]. Mean values of the extent of microbial colonization were used to describe the results graphically. For statistical evaluation, using the Mann-Whitney U test $(\alpha=0.05)$, we compared the singleand the corresponding multi-component adhesive (groups 1 and 2, 3 and 4, 5 and 6,7 and 8, respectively). We also combined groups 1 and 2 in a Z100 MP group, groups 3 and 4 in a Tetric Flow group, groups 5 and 6 in an XRV Herculite group, groups 7 and 8 in an Arabesk Top group. The Z100 MP group was then compared with the Tetric Flow group and the XRV Herculite group with the Arabesk Top group.
The variable type of colonization was divided into three groups: microbial colonization mainly proceeding from (1) dentin margin (more microorganisms were found in the apical half of the cavity); (2) enamel margin (more microorganisms were found in the coronal half of the cavity), and (3) colonization equally proceeding from enamel and dentin margin (microorganisms were evenly distributed over the apical and coronal cavity walls).

\section{Results}

Histological examination revealed only Gram-positive rod-shaped and coccal bacteria and no foreign bacteria in the cavities. In addition, microbiological tests of the incubation medium revealed the presence of only $S$. mutans and L. acidophilus.

The extent of microbial colonization is presented in table 3. The amount of microbial colonization for all the tested composite adhesive systems was very small (predominantly score 1: single microorganisms on the cavity 
Table 3. Extent of microbial colonization of marginal gaps for each composite adhesive system

\begin{tabular}{|c|c|c|c|c|c|c|c|c|}
\hline \multirow{2}{*}{\multicolumn{2}{|c|}{ Groups }} & \multirow[t]{2}{*}{$\begin{array}{l}\text { Total } \\
\text { sections }\end{array}$} & \multirow{2}{*}{$\begin{array}{l}\text { Mean } \\
\text { extent of } \\
\text { colonization }\end{array}$} & \multicolumn{5}{|c|}{$\begin{array}{l}\text { Extent of microbial colonization of } \\
\text { marginal gaps, number of sections }\end{array}$} \\
\hline & & & & score 0 & score 1 & score 2 & score 3 & score 4 \\
\hline 1 & Scotchbond 1/Z100 MP & 72 & 1.01 & 4 & 63 & 5 & 0 & 0 \\
\hline 2 & Scotchbond Multi-Purpose/Z100 MP & 72 & 0.94 & 8 & 60 & 4 & 0 & 0 \\
\hline 3 & Syntac Single-Component/Tetric Flow & 72 & 0.92 & 8 & 62 & 2 & 0 & 0 \\
\hline 4 & Syntac/Tetric Flow & 72 & 0.85 & 13 & 57 & 2 & 0 & 0 \\
\hline 5 & OptiBond Solo/XRV Herculite & 66 & 0.68 & 22 & 43 & 1 & 0 & 0 \\
\hline 6 & OptiBond FL/XRV Herculite & 66 & 0.77 & 15 & 51 & 0 & 0 & 0 \\
\hline 7 & Solobond M/Arabesk Top & 72 & 0.97 & 2 & 70 & 0 & 0 & 0 \\
\hline 8 & Solobond Plus/Arabesk Top & 72 & 0.99 & 1 & 71 & 0 & 0 & 0 \\
\hline
\end{tabular}

wall and/or within the detached layer). Scores 0 and 2 occurred rarely and scores 3 and 4 did not occur at all. The mean values of bacterial colonization were different for each of the systems and varied from 0.68 to 1.01 (table 3). With respect to the extent of microbial colonization of marginal gaps, there were no significant differences between the single-component and the corresponding multicomponent adhesives from the same manufacturer. Z100 MP restorations in combination with single- and multicomponent adhesives demonstrated a significantly stronger microbial colonization of marginal gaps than restorations using Tetric Flow systems. XRV Herculite adhesive systems demonstrated significantly less microbial colonization of marginal gaps than Arabesk Top adhesive systems (table 4).

In all groups, microbial colonization of marginal gaps proceeding from the apical dentin margin of the cavity was more frequent than that proceeding from the coronal enamel margin, whereas the microbial colonization extent of the coronal enamel margin and apical dentin margin were usually equal (table 5).

\section{Discussion}

All composite adhesive systems examined had good marginal adaptation. Statistically, there were no significant differences found in the intensities of bacterial colonization. This means that the single-component adhesives demonstrated a similarly stable bonding to the tooth tissue than the proven multi-component adhesives. These results agree with those of Vargas et al. [1997] and Swift et al. [1998]. The single-component OptiBond Solo actually has a higher bond value to enamel and sometimes to den-
Table 4. Comparison of microbial colonization of marginal gaps between Z100 MP and Tetric Flow systems, and between XRV Herculite and Arabesk Top systems

\begin{tabular}{llc}
\hline Groups & $\begin{array}{l}\text { Extent of microbial } \\
\text { colonization of marginal gaps }\end{array}$ \\
\cline { 2 - 3 } & mean p \\
\hline Z100 MP (groups 1 and 2) & 0.98 & 0.037 \\
Tetric Flow (groups 3 and 4) & 0.88 & \\
\hline XRV Herculite (groups 5 and 6) & 0.73 & $<0.001$ \\
Arabesk Top (groups 7 and 8) & 0.98 & \\
\hline
\end{tabular}

tin than the multi-component OptiBond FL [Reality Publishing Co., 1999; Phrukkanon et al., 1998]. From dye penetration studies, Settembrini et al. [1997] and Castelnuovo et al. [1996] concluded that a one-step dentinbonding system effectively prevents leakage in Class $\mathrm{V}$ restorations at both composite-enamel and compositedentin tooth surface interfaces, while Pilo and Ben-Amar [1999] found no significant differences between the single- and multi-component dental adhesives.

Procedures for groups 1-4 differed from those used for groups 5-8 (one- and respective two-layer technique, different number of thermocycles). These two main technique groups test different materials and therefore one cannot determine from the results whether the identified differences relate to differences in techniques or differences in materials. Therefore only Z100 MP can be compared with Tetric Flow restorations and XRV Herculite with Arabesk Top restorations to test material-related differences. The cavity walls of Z100 MP restorations 
Table 5. Distributions of patterns of microbial colonization of marginal gaps for each composite/adhesive system

\begin{tabular}{|c|c|c|c|c|c|c|}
\hline \multirow{2}{*}{\multicolumn{2}{|c|}{ Groups }} & \multirow{2}{*}{$\begin{array}{l}\text { Total } \\
\text { sections }\end{array}$} & \multirow{2}{*}{$\begin{array}{l}\text { Sections } \\
\text { with } \\
\text { penetration }\end{array}$} & \multicolumn{3}{|c|}{ Pattern of microbial leakage, $\%$} \\
\hline & & & & $\begin{array}{l}\text { equal penetration } \\
\text { from enamel and } \\
\text { dentin margin }{ }^{1}\end{array}$ & $\begin{array}{l}\text { penetration } \\
\text { mainly from } \\
\text { dentin margin }{ }^{2}\end{array}$ & $\begin{array}{l}\text { penetration } \\
\text { mainly from } \\
\text { enamel margin }\end{array}$ \\
\hline 1 & Scotchbond 1/Z100MP & 72 & 68 & 56 & 28 & 16 \\
\hline 2 & Scotchbond Multi-Purpose/Z100 MP & 72 & 64 & 62 & 22 & 16 \\
\hline 3 & Syntac Single-Component/Tetric Flow & 72 & 64 & 47 & 36 & 17 \\
\hline 4 & Syntac/Tetric Flow & 72 & 59 & 64 & 19 & 17 \\
\hline 5 & OptiBond Solo/XRV Herculite & 66 & 44 & 45 & 32 & 23 \\
\hline 6 & OptiBond FL/XRV Herculite & 66 & 51 & 72 & 20 & 8 \\
\hline 7 & Solobond M/Arabesk Top & 72 & 70 & 87 & 13 & 0 \\
\hline 8 & Solobond Plus/Arabesk Top & 72 & 71 & 77 & 23 & 0 \\
\hline \multicolumn{7}{|c|}{ Similar numbers of microorganisms on the apical and coronal cavity walls. } \\
\hline \multicolumn{7}{|c|}{ More microorganisms in the apical half of the cavity. } \\
\hline 3 & \multicolumn{6}{|c|}{ More microorganisms in the coronal half of the cavity. } \\
\hline
\end{tabular}

showed more extensive colonization than Tetric Flow restorations. Physical characteristics are probably the source of this difference. In contrast to the heavily filled composite Z100 MP, Tetric Flow is a flowable composite. This type of material has a smaller elastic modulus (e.g. for Tetric Flow only 5.3 GPa) than the harder composites (e.g. for Z100 MP $13.0 \mathrm{Gpa}$ ) and is therefore more resilient. This feature could allow Tetric Flow to better tolerate the stress related to the shaping of the tooth and reduce the stress on the bond to the tooth. This would serve as a stress breaker, resulting in better adaptation to the cavity walls [Frankenberger, 1999; Lang et al., 1996, Swift et al., 1995]. Composite resins shrink during polymerization, to an extent depending, like the elastic modulus, on the filler content [Labella et al., 1999, Price et al., 2000, Swift et al., 1995]. Flowable composites shrink more than heavily filled composites, which might indicate a potential for higher interfacial stresses [Labella et al., 1999, Obici et al., 2002]. However, lower rigidity of the flowable composites may be a counteracting factor [Labella et al., 1999]. Z100 MP has a polymerization shrinkage of 3.0\% and Tetric Flow of 4.4\% [Soltész, 1998]. Low-modulus composites can relieve some of the polymerization contraction stresses by flow relaxation, whereas high-modulus materials can compensate less well for such stresses [Labella et al., 1999, Swift et al., 1995].

In the present study, the cavity walls of XRV Herculite restorations were significantly less colonized with bacteria than Arabesk Top restorations. OptiBond Solo and OptiBond FL are filled adhesives as opposed to the unfilled adhesives Solobond M and Solobond Plus. Filled adhe- sives can impart an added flexibility to a restoration done with a relatively stiff hybrid composite. This flexibility can help to reduce the stress at the interface between the restoration and the tooth caused by polymerization shrinkage [Reality Publishing Co., 2000]. This produces a much better quality margin. In their comparative investigation of different dentin adhesives, Blunck and Roulet [1997] found that restorations using OptiBond FL as the bond medium had the highest margin quality and suggested that, because this is a filled adhesive, it forms a thicker layer that acts like an elastic band and absorbs outside forces.

The initial strength after application of dentin-bonding agents is as good as those of composite-enamel bonding, but the endurance under oral conditions is still inadequate [Tinschert et al., 1997]. Despite modern dentin adhesives, marginal adaptation to dentin is still worse than to enamel [Hickel, 1997]. Thus it was to be expected that bacterial colonization of the coronal (enamel) aspect of the cavities would be less than that of the apical (dentin) side. This was true for all groups. The most predominant form found was, however, a colonization proceeding equally from enamel and dentin margins.

A microbiological testing system was chosen for the investigation of single- and multi-component dental adhesive systems because it better simulates the real situation in the oral cavity than dye penetration tests, and is clinically relevant since it is directly linked to the development of secondary caries and pulp irritation. However, the model has limitations. 
(1) Pulp inflammation may be caused by both microorganisms and their toxins, but our model concerns only the bacteria.

(2) Our model does not take into account hydration or pulpal pressure of vital in vivo dentin [Pashley, 1991].

(3) Our method does not allow quantitation of all microorganisms present; the restorations were not sampled in situ by grinding, and the removal of the stiff fillings from the decalcified dentin entails the risk of partially removing adherent microorganisms, so we could only detect microorganisms adhering to dentin. However, such microorganisms are capable of penetrating towards the pulp.

(4) The dissolution of enamel by EDTA prevents direct evaluation of the marginal adaptation to enamel; it can only be estimated indirectly through the assessment of the subjacent dentin.

In conclusion, the single-component dental adhesives achieved marginal adaptation of composites comparable to that of multi-component adhesives in vitro. The extent of microbial leakage was very low in all tested composite adhesive systems. Long-term clinical data are required.

\section{Acknowledgments}

The authors would like to thank the medical-technical assistant, Gabriele Körtel, as well as the dentists, Anke Herrmann and Matthias Rehbach, for their involvement.

\section{References}

Abdalla AI, Davidson CL: Bonding efficiency and interfacial morphology of one-bottle adhesives to contaminated dentin surfaces. Am J Dent 1998;11:281-285.

Blunck U: Dentinhaftmittel und Kompomere. Quintessenz 1996;47:19-35.

Blunck U, Roulet JF: Effect of water storage on the effectiveness of dentin-bonding agents. Dtsch Zahnärztl Z 1997;52:806-808.

Brown JH, Brenn L: A method for the differential staining of Gram-positive and Gram-negative bacteria in tissue sections. Bull Johns Hopkins Hosp 1931;48:69-73.

Castelnuovo J, Tjan AH, Liu P: Microleakage of multi-step and simplified-step bonding systems. Am J Dent 1996;9:245-248.

Dammaschke T, Schäfer E: Selbstkonditionierende Dentinadhäsive ohne Abspülen: Eine neue Generation von Dentinhaftvermittlern. Teil 1. ZWR Dtsch Zahnärztebl 2000;109:30-34.

Frankenberger R: Fliessfähige Komposite (Flowables). Quintessenz 1999;50:1145-1154.

Fusayama T: Posterior adhesive composite resin: A historic review. J Prosthet Dent 1990;64:534538.

Fusayama T: The progress and results of revolution in dental caries treatment. Int Dent J 1997;47: 157-166.

Haller B, Fritzenschaft A: Bond strength of singleand multi-component bonding agents in dry and moist bonding trials in vitro. Dtsch Zahnärztl Z 1999;54:225-230.

Haller B: Mechanism of action and efficacy of dentin adhesives. Dtsch Zahnärztl Z 1994;49:750759.
Hickel R: Modern filling materials. Dtsch Zahnärztl Z 1997;52:572-585.

Klimm W, Buchmann G, Dorniok R, Pöschmann M, Koch R: Microbial microleakage of class V restorations in vitro. Dtsch Zahnärztl Z 1996; 51:90-95.

Labella R, Lambrechts P, Van Meerbeek B, Vanherle G: Polymerization shrinkage and elasticity of flowable composites and filled adhesives. Dent Mater 1999;15:128-137.

Lang H, Schwan R, Nolden R: Deformation of class $\mathrm{V}$ restorations under loading. Dtsch Zahnärztl Z 1996;51:613-616.

Lutz F, Krejci I, Schüpbach P: Adhäsivsysteme für zahnfarbene Restaurationen. Schweiz Monatsschr Zahnmed 1993;103:537-549.

Obici AC, Sinhoreti MAC, de Goes MF, Consani S, Sobrinho LC: Effect of the photo-activation method on polymerization shrinkage of restorative composites. Oper Dent 2002;27:192198.

Pashley DH: In vitro simulations of in vivo bonding conditions. Am J Dent 1991;4:237-240.

Phrukkanon S, Burrow MF, Tyas MJ: Effect of cross-sectional surface area on bond strengths between resin and dentin. Dent Mater 1998;14: 120-128.

Pilo R, Ben-Amar A: Comparison of mikroleakage for three one-bottle and three multiple-step dentin bonding agents. J Prosthet Dent 1999; 82:209-213.
Price RB, Rizkalla AS, Hall GC: Effect of stepped light exposure on the volumetric polymerization shrinkage and bulk modulus of dental composites and an unfilled resin. Am J Dent 2000,13:176-180.

Reality Publishing Co.: Dental adhesives. Reality 1999;13:1-201.

Reality Publishing Co.: Dental adhesives. Reality 2000;14:1-195.

Schäfer E: Geschichtliche Entwicklung, Klassifizierung und Haftungsmechanismen der Dentinadhäsive. 1. Grundlagen der Dentinadhäsion und Adhäsive der 1. bis zur 3. Generation. ZWR Dtsch Zahnärztebl 1999;108:218-225.

Settembrini L, Gultz JP, Scherer W, Kaim J: A single-component bonding system microleakage study. Gen Dent 1997;45:341-343.

Soltész U: Polymerisationsschrumpfung einiger neuer Komposit-Füllungswerkstoffe. Zahnärztl Mitt 1998;88:1440-1446.

Swift EJ, Perdigao J, Heymann HO: Bonding to enamel and dentin: A brief history and state of art. Quintessence Int 1995;26:95-110.

Swift EJ, Perdigao J, Heymann HO: Enamel bond strengths of 'one-bottle' adhesives. Pediatr Dent 1998;20:259-262.

Tinschert J, Wilke M, Esser M, Marx R: Bond strength and hydrolysis resistance of modern dentin bonding agents. Dtsch Zahnärztl Z 1997;52:295-298.

Vargas MA, Cobb DS, Denehy GE: Interfacial micromorphology and shear bond strength of single-bottle primer/adhesives. Dent Mater 1997; 13:316-324. 